No. XXXVI.-Notes on a Seution seen in a Drain on the Landos of Davieland, near Thornlifbank. By Jamrs NeILSON.

[Read 14th April, 1904.]

THe drain in question runs parallel to the road which leads from the west end of Thornliebank to Clarkston, and about 50 yards south of the same.

It was pointed out to us during an excursion of the Glasgow Geological Society in November, 1903.

The specimens referred to were taken from a point about 200 yards east of the boundary of the Rouken Glen Park.

Unfortunately it was dusk ere we arrived, and we could only secure a few specimens.

I made another trip a few days later, only to find that the drain was being filled up, and, what between the slush and the men working in the hole, I was unable to get the proper section or to secure enough specimens to piece together what I consider one of the most interesting bits of local history that has turned up of late years.

The best section I saw was something like the following:-

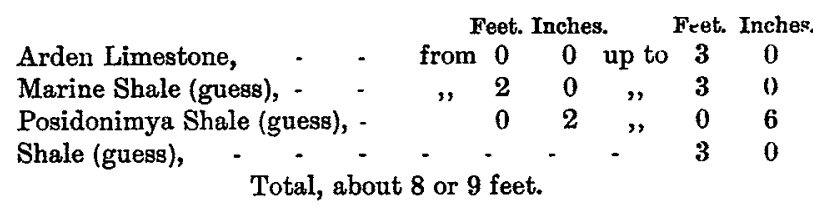

Most of our Marine Limestones have a bed of coal lying at a short distance underneath, and the Arden is no exception to this rule, although it was not seen in this section.

The Arden Limestone has been extensively wrought in this district for many years, but as the work ceases at the bottom of the Limestone I have never before seen these shales exposed.

Our late respected Vice-President, John Young, LL.D., however, recorded the finding of these shales in a drain at Arden Old Limestone Quarry, about a mile west from here. This was recorded in the year 1865, and the drain was shortly after- 
NEILSON-DRATN SWOTION ON DAVIELAND, THORNLIEBANK. 295

wards covered up, and, so far as I am aware, has never been observed from that time (see Trans., vol. ii., 70-1).

These same beds may be seen exposed in natural section at Linn Spout, Dalry, and are described by Mr. Robert Craig in the Transactions, ${ }^{*}$ the section being as follows:-

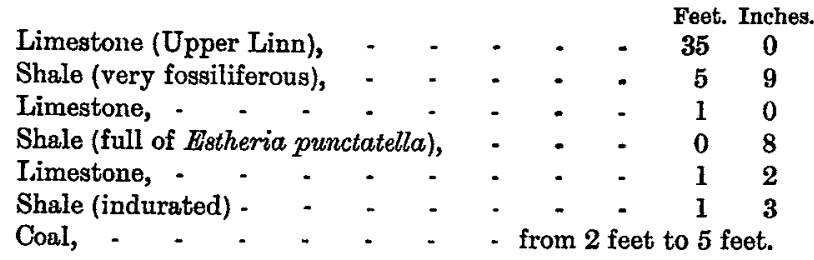

The lowest bed exposed in the drain at Davieland is a dark, slightly carbonaceous shale. It readily splits into thin, smooth, parallel slabs. Mr. Young calls it "Alum Shale," but my attention not having been directed to this I am not in a position to make any comment.

Overlying (?) this shale is another which contrasts with it very much, especially in that it is charged with fossils, so for want of a better name I call it meantime the "Estheria Shale," because of the prevalence of two shells formerly referred to that genus, and one of which I meantime retain the name.

Unfortunately I cannot give its thickness. The specimens I have do not show more than about 2 inches. At Linn Spout this shale is 8 inches thick, but $I$ am inclined to think it is less here. It undergoes rapid deterioration (which affects also the contained fossils) through exposure to the atmosphere. Mr. John Young speaks of it as an alum shale, and probably its rapid deterioration may be due to the action of that salt.

I cannot even tell from my specimens which is the top side, the only means I have of judging being some two or three pick marks, and if these have been struck while the slabs were in position that would show the top side. The shale splits easily into thin slabs, in which are thin lines of fossils. The peculiarity of these specimens is that the fossils suddenly appear in enormous numbers in thin zones, then within a short space (1-16 of an inch or so) these fossils suddenly and entirely

* "On the Upper Limestones of North Ayrshire, \&o."-Trans. Geol. Soc. of Glasgow, vol. viii., p. 28. 
disappear, and are replaced by a barren zone 1-16 inch to $\frac{3}{8}$ inch in thickness. Then occurs another fossil band, also about 1-16 inch thick, but filled by entirely different fossils, followed by another barren zone, and so on.

One of the specimens exhibited shows 5 life zones with the 4 barren zones, all within a space of $\frac{1}{2}$ inch.

These may be numbered as follows:-

1st. Posidonimya Youngi zone.

2nd. Posidonimya Youngi, \&c., zone.

3rd. Fish (Acrolepis Hopkinsi) zone.

4th. Posidonimya punctatella (small size) zone.

5th. Marine Fry zone, mostly Actinopteria (Pteronites) persulcata.

From other specimens I conclude that there is probably more than one zone of $\boldsymbol{P}$. punctatella (small size) and of marine fry, and these are underlaid (?) at a distance of about $\frac{3}{8}$ inch by a zone of

6th. Posidonimya punctatella of very large size up to $1 \frac{8}{8}$ inch by 1 inch.

There is still another zone, that of

7th. Lingula squamiformis.

It is situated within $\frac{3}{8}$ inch of a zone of $P$. punctatella (small), but which or where I am unable to say.

8th. Overlying all there is the marine shale, which does not split, but breaks up into irregular pieces, and is charged with all the usual characteristic marine forms, among which the brachiopods, Productus and Athyris, are the most common.

\section{Posidontmya Shate.}

The first mention of this shale is in a paper read by the late Dr. John Young before this Society on 13th April, 1865,* where the principal fossil is described by Professor T. Rupert Jones under the name of Estheria punctatella, on account of certain minute shell structure which he considered characteristic of Crustacea.

Again, on 13th March, 1890, another notice appeared in the Trans., $f$ in which Professor Jones alters the genus from

"Trans., vol. ii., p. $71 . \quad$ † Vol. ix., p. 79, and plate v. 
NEILSON-DRATN SMOTION ON DAVIELAND, THORNLIEBANK. 297

Estheria to Posidonimya (a bivalve mollusc), and also describes Estheria Youngi as a crustacean.

It is to be noticed that the shale from which this latter shell was described had been in Dr. Young's possession for more than twenty years. Owing to deterioration the fossils could not be so well seen as in the fresh specimens now produced, and there is reason to think that it also is a mollusc, and probably belongs to the same genus as the preceding.

Professor Jones has also referred to these shells while describing some Siberian specimens. ${ }^{*}$

Dr. Young speaks of Estheria punctatella $\dagger$ as having been got in alum shales at Campsie and in an aluminous shale at Braehead, near Busby. I know Braehead pretty well, but have never observed anything resembling it there, nor does Dr. Young ever mention that locality in any subsequent publication, so I presume it may be dismissed.

In Young and Armstrong's list, 1871, $\$$ the following localities are given for Estheria punctatella:-Arden in alum shale; Ist Kingshaw Limestone, Carluke; South Hill and Glorat, Campsie, in alum shale.

In the "Catalogue of Western Scottish Fossils," 1876 (compiled for British Association by James Armstrong, John Young, and David Robertson), the three latter localities are dropped out, and the localities given are Arden and Linn Spout, Dalry.

This, however, does not necessarily mean that the authors had abandoned those other localities, as pressure was brought to bear by the Committee of the British Association to keep the book down to the smallest possible limit, which was done by omitting the localities.

This course was also adopted in the 1901 British Association Catalogue, and constitutes, in my opinion, the greatest defect of these books, which for zoning purposes are of comparatively little use, and certainly will never supersede the Catalogue of 1871.

Again, in $1890, \S$ the localities given are Arden and Linn Spout, while in "The Geology of the Campsie District," by Dr. John Young, 3rd edition, 1893, none of these fossils are given.

* Geol. Mag., 1901, p. 434. + Trans., vol. ii., p. 72.

\$Trans., vol. iii., appendix, p. 30. $\$$ Trans., vol. ix., pp. 80 and 84 . 
I understand that no specimens from other localities are in Dr. Young's collection (now in the Kelvingrove Museum, Glasgow), and, as Mr. John Smith says he knows of none, I think we may take it as proved that the only known localities for these shells are Thornliebank and Linn Spout.

As these localities are on one geological horizon, we are faced by the interesting fact that these shells suddenly appear in myriads on this horizon, and after flourishing for a very short period are as suddenly cut off and disappear, so far as we know, for ever.

This seems to traverse all our ideas of evolution and development, as, according to these, there ought to be a slow transition from allied forms, and when a comparatively stable form had been reached a considerable time ought to elapse before the shell grew so numerous as practically to monopolise the whole bottom of the water, as we see this does. Yet the whole happens so suddenly that within a space of time measured by 1-16 of an inch, the shell has appeared and disappeared, and, after two or three alternations, disappears, so far as we know, for ever. There were doubtless places outside the area of our observations where it developed and where it survived during these barren intervals, but these are, in the meantime, at least, "missing links."

The Estheria Youngi and the smaller form of P. punctatella cover the surface so completely that often the shale itself is not seen at all. The larger shells are not quite so closely packed. There is, however, no appearance of any other organism in the same layer.

It seems to us that these shells indicate fresh-water conditions, of which the above monopoly is characteristic, and this seems also to have been the opinion of Mr. Young and Professor Rupert Jones, as Estheria is a distinctly fresh-water genus.

Zone No. 3-Fish Zone.-So called because it contains numerous bones, scales, and teeth of Ganoid fishes, among which Acrolepis Hopkinsi has been identified. I am also under the impression that this represents fresh-water conditions. As the distance between Zones 2 and 4 is only about $\frac{1}{8}$ inch, some of the fish remains appear as touching each of 
NEILSON-DRAIN SECTION ON DAVIELAND, THORNLIEBANK. 299

these zones, but I am of opinion that they formed a distinct zone, in which none of the inhabitants of Zones 2 or 4 lived.

No. 5-Marine Fry Zone.-There appear to be several of these. The surface is charged with the fry of marine Lamellibranchs, mostly from under 1-16 inch to about $\frac{1}{8}$ inch in length. Scattered among these is a number of minute spiral shells, probably belonging to the Murchisonia group, and also a number of straight shells, probably Orthoceras, some of these being of much larger growth.

The most interesting shell of this group is, however, a small one, formerly known as Pteronites, now Actinopteria persulcata (M'Coy), which occurs in hundreds to the square foot. The peculiarity of this shell is that in its young state the posterior portion of each valve is only very slightly calcareous, or possibly membranous, and is not preserved in a fossil state, so that the long rib forming the hinge line appears like a handle to the shell, the whole looking like some peculiarly shaped axe or one-sided harpoon.

As the shell grows in age this gap fills up, and we know it as A. persulcata M'Coy.

In my opinion these zones represent a period during which the sea broke into this hitherto confined fresh-water space, carrying with it the fry of a number of marine species, which at that age are free, and either float or swim. These conditions lasted only a very short time, not long enough to allow of these fry reaching maturity, and were again replaced by fresh-water conditions. There are, however, several specimens of Orthoceras, which certainly are not fry, but then it has to be remembered that this species, like our modern cuttle fish or octopus, was a powerful swimmer, and probably came here in pursuit of the smaller animals.

As showing that the water at this time was rather inclined to be brackish, it may be mentioned that the more intensely marine types-Brachiopods, Encrinites, and Corals-are conspicuous by their absence.

Zone No. 6-Characterised by $P$. punctatella of very large size up to 13 inch by 1 inch.

These are not so thickly crowded together as the smaller size, yet they cover something like two-thirds of the entire surface of the shale. If, as I take it, this is older than Zone 4, 
then the shell must have been at its best at the first, and suffered a period of deterioration before Zone 4 appeared. How far this deterioration continued I cannot say, but it is quite possible that $P$. Youngi may be a further deterioration in the struggle for existence before final extinction. Should this not be the case, then it is probable that the two species may have had a common ancestry.

Zone No. 7-Characterised by the presence of Lingula squamiformis of fairly large size.-This is a truly marine brachiopod shell, but possesses the peculiarity that it does not thrive under intense marine conditions, but thrives best in brackish water, and in our own beds a very interesting life history could be traced, marked by the diminishing number of associated marine forms as the water became fresher, until it attains its greatest size in the fossil series, in water so fresh as to kill off every other marine form, yet not fresh enough to permit of the existence of fresh water forms of life. In the present instance it is associated with one or two small marine forms and two small specimens of Posidonimya.

The mode in which the above fossils are preserved is somewhat puzzling. They are all pretty much crushed, yet the exterior has been so well preserved that the minute shell structure can still be traced. Yet, although in numerous instances the interior of the shell is exposed, this appears to have been partly dissolved away, so that now no details of the hinge nor of the muscle scars are preserved, so that the position of these so-called Posidonimyas is doubtful.

Dr. Young tells us they had already been referred to Posidonia, Leptodomus, Sanguinolites, Estheria, and now Posidonimya, but when next they appear in public they may be christened by a new name, but whether Edmondia, or Carbonicola, or some other name, time alone will tell. They will probably be refigured in Dr. Wheelton Hind's Monograph on Carboniferous Lamellibranchiata in the forthcoming number of the Palæontographical Society.

This remark as to preservation also applies to the Orthocerases, which are squeezed flat, so that it is only in rare cases that we can say whether they belong to that genus or to Dentalium. 
NEILSON-DRAIN SECTION ON DAVIRLAND, THORNLIEBANK. 301

I have never before seen Orthoceras in this state; the heavy siphuncle and strong septro keeping this shell solid and circular in at least its smaller sizes. I am inclined to attribute this condition to the fact that the epidermis protected the exterior of the shell, while the interior was attacked by impurities in the water, and this theory is strengthened by the fact that Actinopteria has suffered least, being, as has been already shown, in a more cartilaginous condition than the others.

The fish remains are not in the least affected.

Having now worked out the details, let us ask, what is the story told by this section?

1st. The bed of coal-Tells of a land surface. It is generally considered that the coal trees grew where we now find the coal, and this shows that for a very long period this was either dry land or a sort of marsh. It is very strange, indeed, that nearly all our marine limestones are underlaid by a bed of coal, which is its very antithesis; this occurs too often to be considered as a coincidence, yet I cannot see how they can be regarded as cause and effect.

2nd. We have a long period represented by several feet of barren shale, in which the conditions were inimical to life. This was probably an enclosed lake charged with some salts.

3rd. Fresh-water conditions, with fossils.

4th. Barren zone, conditions inimical to life.

5th. The sea forces its way in, depositing minute fry; is again expelled, and again returns.

6th. Barren zone.

7th. Fresh-water conditions, $P$. punctatella, small size.

8th. Fresh water, but conditions changed; shells have disappeared, and only fish remains are found.

9th. Fresh water, Posidonimya Youngi, Zone 2.

10th. Barren zone.

11th. Fresh water, Posidonimya Youngi, No. 1.

12th. A period in which the sea returned and produced brackish conditions, evidenced by the Lingula.

13th. Marine shale-Truly marine conditions charged with life, but occupying some place not very far removed 
from land, and near to some river, which brought down the mud in which the shells lived.

14th. Arden Hydraulic Limestone-A marine band near the estuary of some river, the fine mud from which, mixing with the lime deposited from sea organisms, \&c., formed that cement-like character for which Arden Lime is known.*

The whole points to slowly sinking strata from dry land through various fluctuations to true marine conditions.

The Posidonimya bed has great persistence, having been recognised at Linn Spout, near Dalry, 18 miles away in a straight line, and is one of our most distinct beds, and as some of its fossils are confined to this bed, and very abundant in it, it is the best bed I know of for life zones. There has also been described from Linn Spout a large crustacean allied to Dithyrocaris, and named Lehiscontia occulata Jones. The specimen is in the possession of Mr. J. Smith, and is meantime unique.

It is, howerer, possible that I have described the series upside down, except the marine shale and limestone, which are undoubtedly at the top, in which case the reading must be reversed.

I have not in the present paper entered into the vexed question of lakes, lagoons, or estuaries, having already done so very freely in a paper on "The Calderwood Limestone and Cement Stone and their Associated Shales." $\uparrow$

Some points, however, I may refer to.

1st. The sea carries with it a very distinct (marine) fauna.

2nd. Estuaries contain this fauna, mixed with fresh water and land remains.

3rd. Fresh-water fauna is quite different from marine, and marine fossils are never got in fresh-water beds.

4th. There does not exist at the present day a third fauna, viz., one differing entirely from either marine or fresh water.

Note.-During the discussion which followed the reading of

* The substance known as Portland Cement is manufactured artificially from a mixture of chalk and Thames or Medway mud.

†Trans., Glasgow Geological Society, 1893, vol. x., p. 61, 
NEILSON-DRAIN SEOTION ON DAVIELAND, THORNLIEBANK. 303

the above paper it was objected that there could not possibly be so many changes from salt to fresh water, as that would involve an incredible amount of oscillation of the crust at this point.

It will, however, be observed that I made no allusion to how these conditions were produced, for the simple reason that in a paper dealing with facts and deductions from these facts it is not advisable to introduce theories of which one can get no passible proof.

As, however, the point has been raised, I may state that it seems to me that all the phenomena may be accounted for by the theory of a slowly sinking area without any upward movement.

We first of all had land, represented by the coal, then we would have a swamp, and then later on a fresh-water lake. As the land continued slowly to sink, the barrier between the lake and the sea would become gradually lower and narrower, till some great tide, helped probably by strong winds blowing shoreward, burst over the barrier, carrying with it its marine fauna. As the waters subsided the lake would gradually become fresher again, and the marine life die and be replaced by the lake forms till the next incursion of the sea.

It is interesting to notice that at the present time the highest spring tides of the year occur about the period of the spring equinox, when the sea is charged with fry of all kinds, and it would be interesting to think that these minute shells represent the equinox in Carboniferous days.

As the land sunk still further the sea gained a permanent footing-represented by the marine shale, and as the land receded and the water became more pure the limestone was deposited.

\section{APPENDIX.}

I sent specimens of the shale to Dr. Wheelton Hind, who has redescribed and refigured the shell first named Estheria punctatella, and afterward Posidonimya punctatella, and has given it a third name, Edmondia punctatella.*

* Monograph of the British Carboniferous Lamellibranchiata, by Wheelton Hind, M.D., B.Sc.Lond., F.R.C.S., F.G.S. ; vol. ii., p. 147, and plate xxv., figs. 12 and 13. London Palæontographical Society, 1904. 
304 TRANSACTIONS-GEOLOGICAL SOCIETY OF GLASGOW.

He says-" The generic affinity is doubtful in the absence of details of the interior, but the shells have none of the special characteristics of Posidonimya, and I am quite at a loss to account for their reference to this very distinct and characteristic genus. The shells are not oblique, and have no posterior winglike projection. For the present I place the species in the genus Edmondia, because there is no lunule and no escutcheon, and the hinge-line appears to be simple and erect. Whatever ligament there was seems to have been internal."

As I was inclined to regard Estheria Youngi as a mollusc, I was disappointed at no reference being made to it by $\mathrm{Dr}$. Hind, but understand it was because none of the specimens were sufficiently well preserved. 